\title{
CHANGING POTENTIAL DISTRIBUTION OF GRAY WOLF UNDER CLIMATE CHANGE IN LAKE DISTRICT, TURKEY
}

\author{
SUEL, $\mathrm{H}^{{ }^{*}}{ }^{*}-\mathrm{MERT}, \mathrm{A}^{2}{ }^{2}-$ YALCINKAYA, B. $^{2}$ \\ ${ }^{I}$ Department of Forestry, Sütçüler Vocational School, University of Applied Science Isparta \\ 32950 Isparta, Turkey \\ ${ }^{2}$ Department of Wildlife Ecology and Management, Faculty of Forestry, University of Applied \\ Science Isparta, 32260 Isparta, Turkey \\ (e-mail:ahmetmert@isparta.edu.tr, bernayalcinkaya48@gmail.com) \\ *Corresponding author \\ e-mail: halilsuel@isparta.edu.tr; phone: +90-530-153-0577; fax: +90-246-351-2901 \\ (Received $1^{\text {st }}$ Aug 2018; accepted 28 $8^{\text {th }}$ Sep 2018)
}

\begin{abstract}
The increase of human activities in recent years has led to many adverse effects and accelerated climate change at an important level. Therefore, it is very important to know how species will be affected by climate change. This study aimed to determine how the distribution of Gray wolf (Canis lupus), one of the most important predator species in the ecosystem, will be affected by climate change. The study was carried out using presence data of this species in the Lake District and the changes in the habitats and distribution of Gray wolf according to the RCP 4.5 and RCP 8.5 (HADGEM2-ES) climate scenarios. We conducted mapping and modelling of the current habitat preferences of Gray wolf using MaxEnt method based on the bioclimatic features derived from the Worldclim. 4 bioclimatic variables (BIO12, BIO13, $\mathrm{BIO} 16$ and BIO19), and 3 environmental variables (slope, ruggedness, topographic position index) were used in the study. The model and maps of the Gray wolf were compared with the future climate scenarios. In conclusion, it is projected that habitats which are determined as suitable for Gray Wolf will decline significantly due to climate change.
\end{abstract}

Keywords: climate change, GIS, Canis lupus, HADGEM2-ES, MaxEnt

\section{Introduction}

Adverse effects of global climate change on ecological systems are increasing day by day. One of the most striking results of global climate change is that Earth's climate has warmed by about $0.6^{\circ} \mathrm{C}$ over the past century and it is estimated that it will increase by $1.4-5.8^{\circ} \mathrm{C}$ in the next century. Regional changes have also been observed in rainfall and humidity levels in the proportion to the rising global temperature (Bellard et al., 2012; Collins et al., 2013; Trenberth et al., 2014).

Changes in the climate are presented in the report prepared by the IPCC (Intergovernmental Panel on Climate Change) and made available to researchers. The data is updated by the IPCC periodically and different scenarios for the future are presented. The last of these reports (IPCC 5th Assessment Report) was announced to the world in Sweden in September 2013 (IPCC, 2013). A report on climate change in Turkey was also prepared by Turkey's State Meteorological Service. In this report, regional climate projections produced by downscaling methods for Turkey were based on global models in the CIMIP5 (Coupled Model Intercomparison Project Phase 5) project and the RCP (Representative Concentration Pathways) scenarios created for the IPCC 5th Assessment Report. RCP 4.5 (which we can describe as moderate) and RCP 8.5 (which we can characterize as pessimistic) were selected. According to the temperature and rainfall projections obtained using HadGEM2-ES (Hadley Centre 
Global Environment Model version 2- Earth System) based on RCP 4.5 scenario for Turkey, it is estimated that temperatures in 2050 will have limited to rise approximately $2 \mathrm{C}$ and precipitation will have decreased by nearly $20 \%$ throughout the whole country. It is also expected that in 2070 temperatures will have increased by $4 \mathrm{C}$ and precipitation will have decrease decreased by $40 \%$ especially in summer. According to the temperature and rainfall projections produced using HadGEM2-ES based on RCP 8.5 scenario for Turkey, it is predicted that in 2050, temperatures will have increased by about $5 \mathrm{C}$ and precipitation will have decreased by about $50 \%$, in 2070 temperatures will have increased by $6^{\circ} \mathrm{C}$, especially in the summer, and rainfall will have decreased by $50 \%$ especially in summer (Akcakaya et al., 2013; Demir et al., 2013; Demircan et al., 2017).

The changes in precipitation and temperatures will affect all living organisms. Most of the research on this subject has focused on plant species and wild animals because these species can easily be affected by climate change challenges and respond in different ways to this situation (Bellard et al., 2012; Gamfeldt et al., 2013). Therefore, the reactions of all species in the food chain to climate change need to be evaluated for sustainability of ecosystems. For this reason, conservationists and researchers need to detect species that are likely to be most affected by the impacts of climate change in order to minimize biodiversity losses due to climate change and the most appropriate approaches should be selected. Therefore, many recent studies have concentrated on modelling species based on ecological needs and projecting those needs onto modelled future climate regimes to predict future potential distributions (Braunisch et al., 2013; Domisch et al., 2013; Porfirio et al., 2014; Pacifici et al., 2015).

Large predators which constitute the top of the food chain are among the most affected species by changes in precipitation and temperature (Gilman et al., 2010). Gray wolves (Canis lupus) may be the most affected large mammalian carnivore by the mentioned negative factors in Turkey.

In addition, these species are in a wide range of motion, especially for searching for food. It is thought that these behaviours often lead them to conflict with humans and livestock, thereby increasing extinction risk (Behdarvand et al., 2014; Ripple et al., 2014). When previous studies on this species in Turkey are examined, it is seen that these studies are limited and generally were carried on population estimates. In these studies, it is stated that the number of individuals belonging to this species is about 5000-7000 (Can, 2008; Akbaba and Ayas, 2012). Contrary to traditional studies, species distribution maps created using modeling techniques for protection of these species are an important basis for conservationists (Guisan et al., 2013; Fourcade et al., 2014). The MaxEnt method, which is one of the modelling techniques used to identify high-quality habitats and determine the ecological factors that are effective in the distribution of species, is a widely preferred modelling and mapping method (Phillips et al., 2004; Barbet-Massin et al., 2012; Mesler, 2015). In this study, it is thought that this method will be useful in estimating the potential distribution of Gray wolf under climate change and monitoring the differences that may occur in future distribution.

The aims of the present study carried out in Lake District are as follows: i) to take inventory of Gray wolf in this area, ii) to determine the climatic factors and environmental variables affecting the distribution of Gray wolf for the present iii) to determine the appropriate habitats for the species by creating the current potential distribution map, and iv) to determine the future potential distribution of species taking future climate scenarios into account (RCP 4.5 and RCP 8.5 scenarios). 


\section{Materials and methods}

\section{Site description}

The study area, Lake District, is located in the Western Mediterranean Region between $38^{\circ} 25^{\prime}-36^{\circ} 06^{\prime} \mathrm{N}$ latitudes and $29^{\circ} 30^{\prime}-32^{\circ} 34^{\prime} \mathrm{E}$ longitudes according to the UTM coordinate system in Turkey (Fig. 1). In terms of climate characteristics, the study area has a very high variation, especially depending on elevation differences. It is possible to say that the average annual precipitation values in the region are between $600-1300 \mathrm{~mm}$ and the annual mean temperature values vary between $12^{\circ} \mathrm{C}$ and $20^{\circ} \mathrm{C}$. The summer drought period in the region lasts for approximately 2-4 months. In general, the area has a transitional climate between the Mediterranean climate and the continental climate. Red pine (Pinus brutia Ten.), Black pine (Pinus nigra Arnold.), various oak species, and juniper species are dominant forest trees in the region.

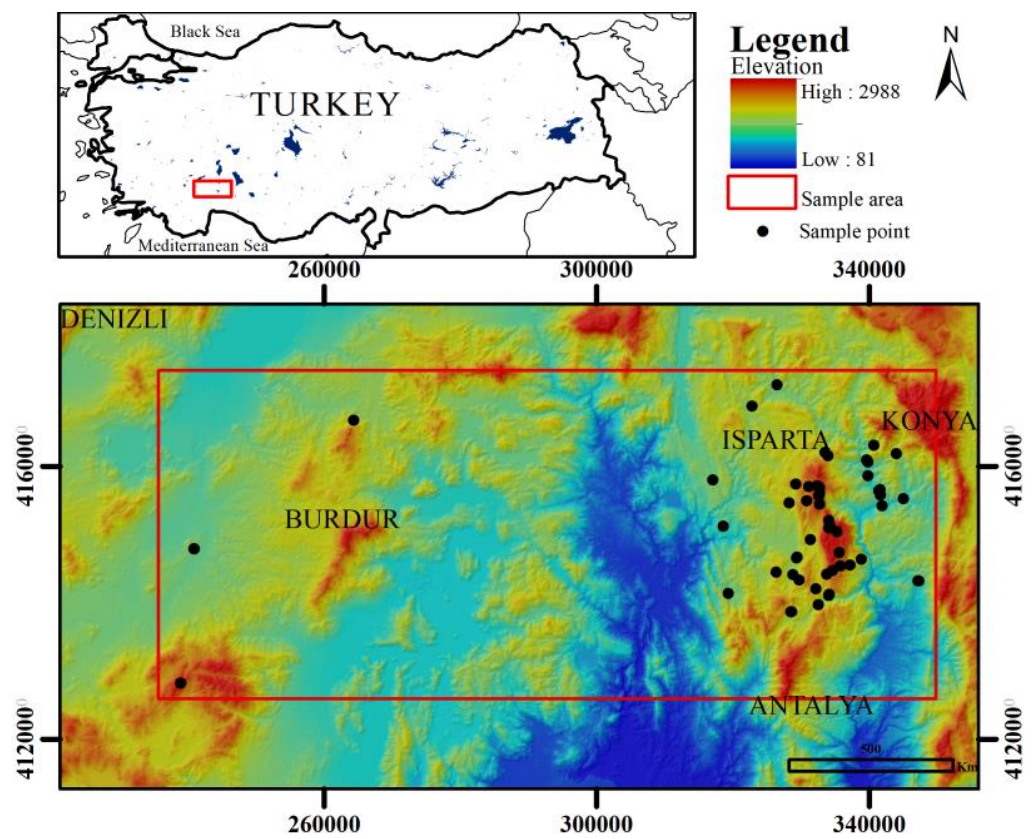

Figure 1. Geographical location of the study area and presence data of Gray wolf

\section{Sampling method}

Tracks and signs of Gray wolf were recorded on field cards by using indirect inventory techniques during the field study. Thus, from 2014 to 2016, feeding signs, footprints, faeces, burrows, and signs of predation belonging to Gray wolf were recorded as presence data at 59 sample points by using absence-presence inventory techniques (Baddeley, 1985).

\section{Data and statistical evaluation}

Scenarios and projections (Table 1) updating at regular intervals were presented in the report prepared by the IPCC and made available to researchers (IPCC, 2013). In this study, 2 of 4 different scenarios, namely RCP 4.5 (which we can describe as moderate) and RCP 8.5 which we can characterize as pessimistic, were selected to create habitat suitability maps of Gray wolf for future scenarios. 
Table 1. Types of representative concentration pathways (RCP's) (based on IPCC, 2013)

\begin{tabular}{c|c|c|c|c|c}
\hline $\begin{array}{c}\text { Name of } \\
\text { RCP's }\end{array}$ & $\begin{array}{c}\text { Radiative } \\
\text { forcing }\end{array}$ & Time & Pathway shape & Concentration (ppm) & $\begin{array}{c}\text { Emissions } \\
\text { (Kyoto Protocol's } \\
\text { greenhouse gases) }\end{array}$ \\
\hline RCP 8.5 & $>8.5 \mathrm{~W} / \mathrm{m} 2$ & In 2100 & Rising & $>\sim 1370$ CO2-eq in 2100 & $\begin{array}{c}\text { Rising continues until } \\
2100\end{array}$ \\
\hline RCP 6.0 & $\sim 6.0 \mathrm{~W} / \mathrm{m} 2$ & $\begin{array}{c}\text { At stabilization after } \\
2100\end{array}$ & $\begin{array}{c}\text { Stabilization without } \\
\text { overshoot }\end{array}$ & $\begin{array}{c}\sim 850 \mathrm{CO} \text {-eq (at } \\
\text { stabilization after } 2100)\end{array}$ & $\begin{array}{c}\text { Decline in the last quarter } \\
\text { of century }\end{array}$ \\
\hline RCP 4.5 & $\sim 4.5 \mathrm{~W} / \mathrm{m} 2$ & $\begin{array}{c}\text { At stabilization after } \\
2100\end{array}$ & $\begin{array}{c}\text { Stabilization without } \\
\text { overshoot }\end{array}$ & $\begin{array}{c}\sim 650 \mathrm{CO} \text {-eq (at } \\
\text { stabilization after } 2100)\end{array}$ & $\begin{array}{c}\text { Decline from the mid- } \\
\text { century }\end{array}$ \\
\hline RCP2.6-PD* & $\sim 3.0 \mathrm{~W} / \mathrm{m} 2$ & $\begin{array}{c}\text { Peak at before } 2100 \\
\text { and then decline }\end{array}$ & Peak and decline & $\begin{array}{c}\text { Peak at } \sim 490 \text { CO2-eq before } \\
2100 \text { and then decline }\end{array}$ & $\begin{array}{c}\text { Decline in the first quarter } \\
\text { of century }\end{array}$ \\
\hline
\end{tabular}

Climate maps were obtained primarily for modelling and mapping. In order to create these maps, 19 different bioclimatic data (available at http://www.worldclim.org) generated by Hijmans et al. (2005) was downloaded in ascii format on a world scale, and then was cut according to the scale of the study area and made ready for use. In the same way, the bioclimatic data to be used in future scenarios (2050, HadGEM2-ES RCP 4.5 and 8.5 scenarios; 2070, HadGEM2-ES RCP 4.5 and 8.5 scenarios) were prepared.

In the next step, maps of environmental variables were created with ArcMap 10.2 software. Firstly, slope, aspect, and elevation maps were created by digital elevation model (DEM) of the study area. Topographic position index, landform position index, ruggedness index, roughness index, topographic convergence index, hill shade index, solar illumination index (6am, 8am, 10am, noon, 2pm, 4pm, 6pm, 8pm), and solar radiation index were then created. Finally, aspect suitability index (ASI) (Eq. 1), radiation index (RI) (Eq. 2) and heat index (SI) values are calculated and mapped. Finally, using different equations; aspect suitability index (ASI), radiation index (RI) and heat index (HI) (Eq. 3) values are calculated and mapped using different equations. The equations for these indices are as follows:

$$
\begin{gathered}
\mathrm{ASI}=\cos (\operatorname{Amax}-A)+1 \\
\mathrm{RI}=\frac{[1-\cos ((\pi / 180)(Q-30))]}{2} \\
\mathrm{HI}=\cos (A-\text { Amax }) * \tan (\text { radian }(\text { slope }))
\end{gathered}
$$

where the value of Amax is 202.50. A, refers to the radian value of aspect. $Q$ refers to aspect. The value of $\pi$ was taken as 3.14159265.

Bioclimatic variables have a high correlation with each other (Süel, 2014). If there is a high correlation between the variables, accuracy and reliability of obtained models decrease. For this reason, Pearson correlation analysis and factor analysis were applied to bioclimatic variables by SPSS software.

MaxEnt 3.4.1 software was used for the determination and modelling of the variables that are effective in the distribution of Gray wolf. For the analysis, the data matrix consisting of bioclimatic variables and environmental variables was recorded as "ascii" file. The presence data of Gray wolf was saved as "csv" file. The data was analyzed via cross validation with $90 \%$ training data of the model, $10 \%$ test data, and 10 replications. The success of the obtained models was assessed according to area under the curve 
(AUC) values in the receiver operating characteristic (ROC) curve. If the model's AUC value is close to 1 , the model is perfect. If it is closer to 0.7 , it is descriptive; however, if it is 0.5 , the model is invalid (Phillips et al., 2004).

As a result of this analysis, the current potential distribution model of the Gray wolf was obtained and the variables affecting the distribution were determined. This model was then simulated for 2050 (HadGEM2-ES RCP 4.5 and 8.5 scenario) and 2070 (HadGEM2-ES RCP 4.5 and 8.5 scenario).

\section{Results}

Presence data of Gray wolf was recorded in 59 sampling points. Pearson correlation analysis and factor analysis were applied to climatic variables due to high correlations among them.

As a result of the factor analysis, four different bioclimatic variables with the best representation ability were obtained: BIO12 (Annual Precipitation), BIO13 (Precipitation of Wettest Month), BIO16 (Precipitation of Wettest Quarter) and BIO19 (Precipitation of Coldest Quarter).

13 different current potential distribution models were obtained for the Gay wolf and the $13^{\text {th }}$ model was chosen as the most suitable model according to AUC values in the ROC curve. The training data AUC value is 0.937 and the test data AUC value is 0.920 for this model (Fig. 2). When the variables affecting the distribution of Gray wolf in the conclusion model were examined, BIO12 (23\%), BIO13 (18.5\%), and BIO16 (21.3\%) were determined as bioclimatic factors and heat index (14\%), aspect (12.4\%), and topographic position index $(10.8 \%)$ were determined as environmental variables.

As a result of simulating the variables obtained in the current habitat suitability model for Gray wolf into the future scenarios, a model with AUC training value of 0.942 and AUC test value of 0.939 was obtained (Fig. 3).

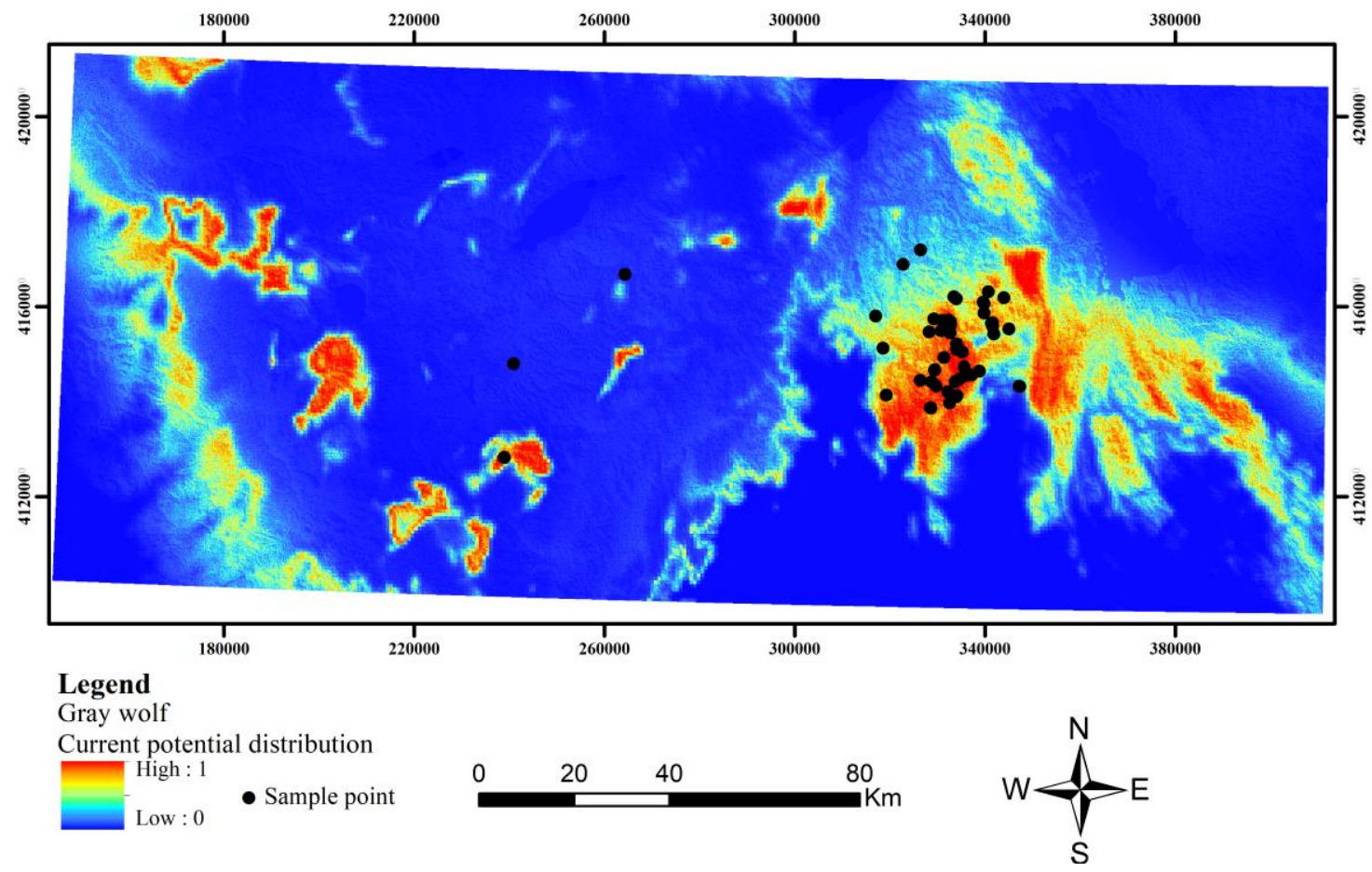

Figure 2. Current habitat suitability maps of Gray wolf 


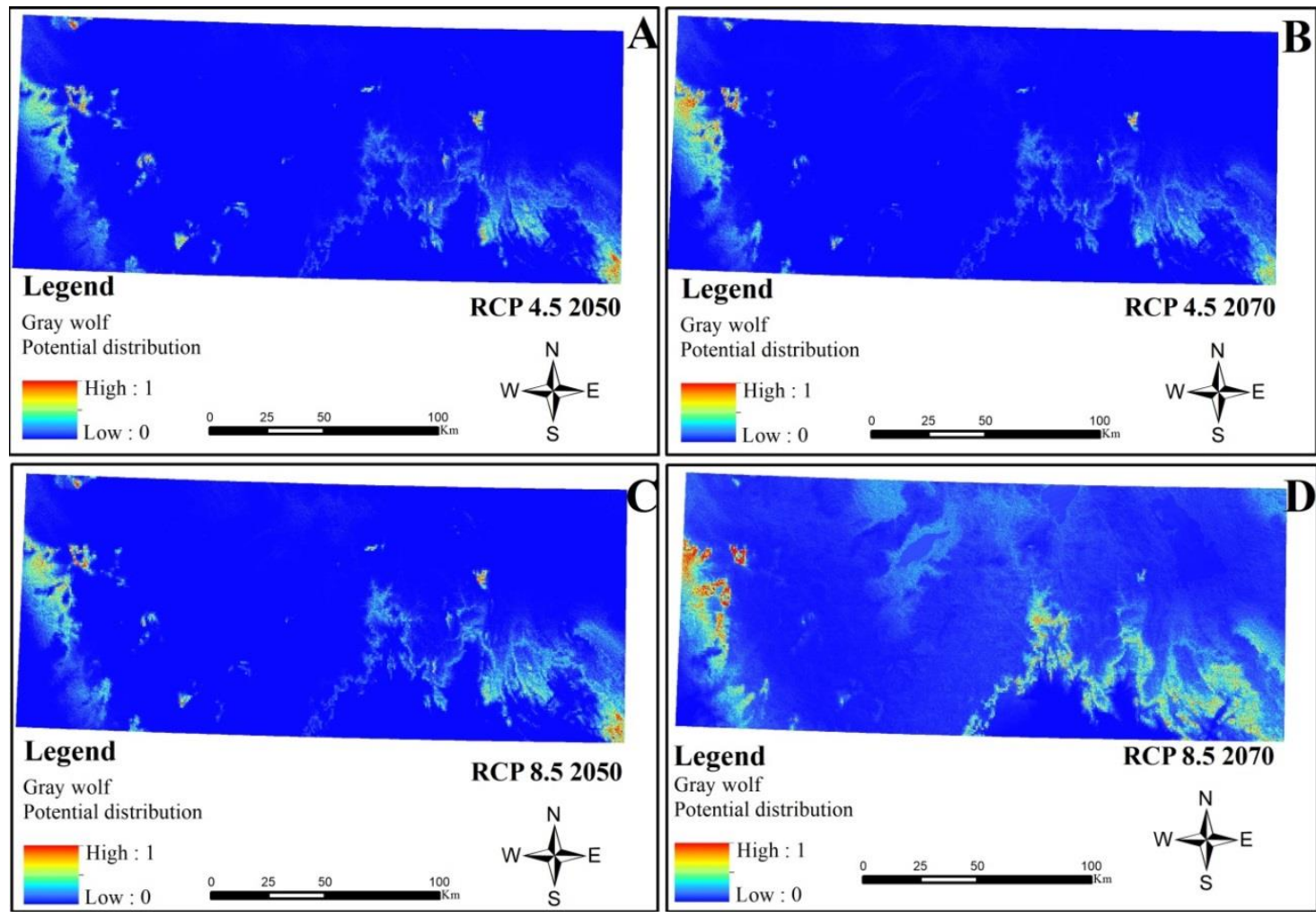

Figure 3. Habitat suitability maps of Gray wolf for future scenarios. A: HADGEM2-ES RCP 4.5 2050, B: HADGEM2-ES RCP 4.5 2070, C: HADGEM2-ES RCP 8.5 2050, D: HADGEM2ES RCP 8.52070

\section{Discussion}

When the current habitat suitability model for Gray wolf is examined using variables ((BIO12 (23\%), BIO13 (18.5\%), BIO16 (21.3\%), heat index (14\%), aspect (12.4\%), topographic position index $(10.8 \%)$ ) which formed the model, it is determined that precipitation and temperature are the most important factors limiting the distribution of this species According to Figure 2, high zones and the eastern part of the study area are more preferred by this species (red coloured areas in maps). However, when the habitat suitability maps (Fig. 3) generated for HADGEM2-ES RCP 4.5 (2050; 2070) and HADGEM2-ES RCP $8.5(2050 ; 2070)$ are examined, it is seen that there would be a significant change in distribution. In other words, depending on climate change, the distribution of the Gray wolf will be affected and the species will migrate in search of a different habitat.

According to the scenario RCP 4.5 2050 (HADGEM2-ES), there is a decrease in the distribution of the wolves, a deviation towards the interior and coastal areas at the same time. A similar change is also observed in the habitat suitability map created for the RCP 4.52070 (HADGEM2-ES) scenario (Fig. 3). However, according to the scenario RCP 4.5 2070 (HADGEM2-ES), this distribution is concentrated towards the western part of the area, whereas the current habitat suitability map shows a distribution in the eastern part of the area. It is thought that the rise in temperature and the decrease in precipitation will cause these changes (Larsen and Ripple, 2006). At the same time, prey species, which are preferred by target species in the field, should be taken into account as to how they will react to possible changes in the future climate. When 
studies on feeding behaviour of the target species in literature are examined, it is stated that they move seasonally by following migratory prey species in their region due to nutritional needs despite being a non-immigrant species (Hof et al., 2012; Metz et al., 2012). In view of this information, it is thought that the hunting species in the area may be another important factor for the change in the distribution of the target from east to west according to the HADGEM2-ES RCP 4.5 scenarios. Diet types of this species vary depending on age, sex, and season. There are also several conditions (weather conditions, the vulnerability of prey species, and wolf density in the region etc.) limiting food availability of Gray wolf (Stahler et al., 2006; Metz et al., 2012).

When habitat suitability maps created according to the scenarios of HADGEM2-ES RCP 8.5, 2050, and 2070 are examined, it is predicted that the potential distribution of goal species in the region will reduce considerably and the distribution will shift to the west and north-west. It is seen that in studies conducted on the general behavior of the species, before setting a new territory or joining any wolf pack, the male wolf can move about $113 \mathrm{~km}$ and their females can move about $78 \mathrm{~km}$. In some cases, they can even show a distribution over $840 \mathrm{~km}$. It is also known that the species prefer to habitat as high as possible, avoiding human influence (Treves and Karanth, 2003).

It is estimated that Gray wolf with high metabolic demand and long distance mobility (Walker and Churchill, 2014) can use coastal areas of the region for any reason such as diet and reach up to Central Anatolia. As can be seen from the HADGEM2-ES RCP 8.5 scenarios, especially in the habitat conformity map created for 2070 , it is proven that coastal area is suitable for distribution of this species. However, it is also probable that human activity which is increasing in coastal areas especially in summer months will limit the movement of the species. To sum up, Gray wolf has to be able to force itself to more movement in order to reduce the effect of negative conditions that will occur in the climate and to be able to return to higher parts where it will feel safe and secure after satisfying its basic needs. According to the habitat suitability maps obtained for both scenarios, it is seen that the results support each other and the distribution of Gray wolf in the region will be affected negatively.

\section{Conclusion}

In conclusion, it is predicted that Gray wolf's habitats will be affected by climate change in the future; however, this situation can be tolerated by the high mobility of this species. Nevertheless, it is clearly seen that there are significant differences between the current potential distribution areas shown in Figure 2 and the potential distribution areas determined for the future scenarios in Figure 3. Due to decreases in the suitable habitats, it is expected that the conflict of this species with human and other animal groups will increase. To sum up, present study should be supported by more detailed studies performed by determining all the variables affecting the habitat in order to prevent the extinction of this species.

Acknowledgements. We thank to project 4123- YL1-14 supported by the Coordination Unit for Scientific Research Projects, Süleyman Demirel University. 


\section{REFERENCES}

[1] Akbaba, B., Ayas, Z. (2012): Camera trap study on inventory and daily activity patterns of large mammals in a mixed forest in north-western Turkey. - Mammalia 76(1): 43-48.

[2] Akcakaya, A., Eskioglu, O., Atay, H., Demir, O. (2013): Yeni senaryolar ile Türkiye için iklim değişikliği projeksiyonları. - Meteoroloji Genel Müdürlügü Matbaası, Turkey.

[3] Barbet-Massin, M., Jiguet, F., Albert, C. H., Thuiller, W. (2012): Selecting pseudo-absences for species distribution models: How, where and how many? - Methods in Ecology and Evolution 3(2): 327-338.

[4] Baddeley, C. J. (1985): Assessments of wild animal abundance. - Forest Research Institute Bulletin 106: 1-46.

[5] Behdarvand, N., Kaboli, M., Ahmadi, M., Nourani, E., Mahini, A. S., Aghbolaghi, M. A. (2014): Spatial risk model and mitigation implications for wolf-human conflict in a highly modified agroecosystem in western Iran. - Biological Conservation 177: 156-164.

[6] Bellard, C., Bertelsmeier, C., Leadley, P., Thuiller, W., Courchamp, F. (2012): Impacts of climate change on the future of biodiversity. - Ecology Letters 15(4): 365-377.

[7] Braunisch, V., Coppes, J., Arlettaz, R., Suchant, R., Schmid, H., Bollmann, K. (2013): Selecting from correlated climate variables: a major source of uncertainty for predicting species distributions under climate change. - Ecography 36(9): 971-983.

[8] Can, O. E. (2008): Camera trapping large mammals in Yenice Forest habitats: A feasibility study for camera trapping large mammals in Yenice Forests, Turkey. Doctoral Dissertation, Orta Doğu Teknik University, Ankara, Turkey.

[9] Collins, M., Knutti, R., Arblaster, J., Dufresne, J. L., Fichefet, T., Friedlingstein, P., Gao, X., Gutowski, W. J., Johns, T., Krinner, G., Shongwe, M., Tebaldi, C., Weaver, A. J., Wehner, M. (2013): Long-term Climate Change: Projections, Commitments and Irreversibility. - In: Stocker, T. F., Qin, D., Plattner, G. K., Tignor, M., Allen, S. K., Boschung, J., Nauels, A., Xia, Y., Bex, V., Midgley, P. M. (eds.) Climate Change 2013: The Physical Science Basis. Contribution of Working Group I to the Fifth Assessment Report of the Intergovernmental Panel on Climate Change. Cambridge University Press, Cambridge, UK and New York.

[10] Demir, O., Atay, H., Eskioglu, O., Tuvan, A., Demircan, M., Akcakaya, A. (2013): RCP 4. 5 Senaryosuna göre Türkiye'de sıcaklık ve yağı̧s projeksiyonları. - III. Türkiye İklim Değişikliği Kongresi-TIKDEK, 3-5.

[11] Demircan, M., Gurkan, H., Eskioglu, O., Arabaci, H., Coskun, M. (2017): Türkiye için iklim değişikliği projeksiyonları: Üç model ve iki senaryo. - Türkiye Su Bilimleri ve Yönetimi Dergisi 1(1): 22-43.

[12] Domisch, S., Araújo, M. B., Bonada, N., Pauls, S. U., Jähnig, S. C., Haase, P. (2013): Modelling distribution in European stream macroinvertebrates under future climates. Global Change Biology 19(3): 752-762.

[13] Fourcade, Y., Engler, J. O., Rodder, D., Secondi, J. (2014): Mapping species distributions with MaxEnt using a geographically biased sample of presence data: A performance assessment of methods for correcting sampling bias. - PloS One 9(5): e97122.

[14] Gamfeldt, L., Snäll, T., Bagchi, R., Jonsson, M., Gustafsson, L., Kjellander, P., RuizJaen, C. M., Froberg, M., Stendahl, J., Philipson, D. C., Andersson, E., Westerlund, B., Andrén, H., Moberg, F., Moen, J., Bengtsson, J. (2013): Higher levels of multiple ecosystem services are found in forests with more tree species. - Nature Communications 4: 1340 .

[15] Gilman, S. E., Urban, M. C., Tewksbury, J., Gilchrist, G. W., Holt, R. D. (2010): A framework for community interactions under climate change. - Trends in Ecology \& Evolution 25(6): 325-331.

[16] Guisan, A., Tingley, R., Baumgartner, J. B., Naujokaitis-Lewis, I., Sutcliffe, P. R., Tulloch, A. I., Regan, J. T., Brotons, L., Mcdonald-Madden, E., Mantyka-Pringle, C., Martin, G. T., Rhodes, R. J., Maggini, R., Setterfield, A. S., Elith, J., Schwartz, W. M., 
Wintle, A. B., Broennimann, O., Austin, M., Ferrier, S., Kearney, R. M., Possingham, P. H., Buckley, M. Y. (2013): Predicting species distributions for conservation decisions. Ecology Letters 16(12): 1424-1435.

[17] Hijmans, R. J., Cameron, S. E., Parra, J. L., Jones, P. G., Jarvis, A. (2005): Very high resolution interpolated climate surfaces for global land areas. - International Journal of Climatology 25(15): 1965-1978.

[18] Hof, A. R., Jansson, R., Nilsson, C. (2012): How biotic interactions may alter future predictions of species distributions: future threats to the persistence of the arctic fox in Fennoscandia. - Diversity and Distributions 18(6): 554-562.

[19] IPCC (Intergovernmental Panel on Climate Change) (2013): Climate Change: The Physical Science Basis. Summary for Policy Makers. - http://www.ipcc.ch/ (accessed on 01.03.2018).

[20] Larsen, T., Ripple, W. J. (2006): Modeling Gray wolf (Canis lupus) habitat in the Pacific Northwest, USA. - Journal of Conservation Planning 2(1): 30-61.

[21] Mesler, J. I. (2015): Modeling habitat suitability and connectivity of Gray wolf (Canis lupus) populations in the Pacific Northwest. - Doctoral Dissertation, Humboldt State University, Arcata, CA.

[22] Metz, M. C., Smith, D. W., Vucetich, J. A., Stahler, D. R., Peterson, R. O. (2012): Seasonal patterns of predation for gray wolves in the multi-prey system of Yellowstone National Park. - Journal of Animal Ecology 81(3): 553-563.

[23] Pacifici, M., Foden, W. B., Visconti, P., Watson, J. E., Butchart, S. H., Kovacs, K. M., Scheffers, R. B., Hole, G. D., Martin, G. T., Akcakaya, R. H., Corlett, R. T., Huntley, B., Bickford, D., Carr, A. J., Hoffmann, A. A., Midgley, F. G., Pearce-Kelly, P., Pearson, G. R., Williams, E. S., Willis, G. S., Young, B., Rondinini, C. (2015): Assessing species vulnerability to climate change. - Nature Climate Change 5(3): 215.

[24] Phillips, S. J., Dudík, M., Schapire, R. E. (2004): A maximum entropy approach to species distribution modeling. - Proceedings of the Twenty-First International Conference on Machine Learning, Banff, Alberta, Canada, pp. 655-662.

[25] Porfirio, L. L., Harris, R. M., Lefroy, E. C., Hugh, S., Gould, S. F., Lee, G., Bindoff, L. N., Mackey, B. (2014): Improving the use of species distribution models in conservation planning and management under climate change. - PLoS One 9(11): e113749.

[26] Ripple, W. J., Estes, J. A., Beschta, R. L., Wilmers, C. C., Ritchie, E. G., Hebblewhite, M., Schmitz, O. J. (2014): Status and ecological effects of the world's largest carnivores. - Science 343(6167): 151-162.

[27] Stahler, D. R., Smith, D. W., Guernsey, D. S. (2006): Foraging and feeding ecology of the Gray wolf (Canis lupus): lessons from Yellowstone National Park, Wyoming, USA. The Journal of Nutrition 136(7): 1923-1926.

[28] Süel, H. (2014): Mapping habitat suitability of game animals in Sütçüler district, Isparta. - Doctoral Dissertation, Suleyman Demirel University, Isparta.

[29] Trenberth, K. E., Dai, A., Van Der Schrier, G., Jones, P. D., Barichivich, J., Briffa, K. R., Sheffield, J. (2014): Global warming and changes in drought. - Nature Climate Change 4(1): 17.

[30] Treves, A., Karanth, K. U. (2003): Human-carnivore conflict and perspectives on carnivore management worldwide. - Conservation Biology 17(6): 1491-1499.

[31] Walker, C. S., Churchill, S. E. (2014): Territory Size in Canis lupus: Implications for Neandertal Mobility. - In: Carlson, K., Marchi, D. (eds.) Reconstructing Mobility. Springer, Boston, MA. 